\title{
EFEKTIVITAS TERAPI MUSIK UNTUK MENINGKATKAN SUBJECTIVE WELL BEING PADA LANJUT USIA DITINJAU DARI JENIS KELAMIN DI WILAYAH PUSKESMAS MODUNG KABUPATEN BANGKALAN
}

\author{
Imam Shofi'i, IGAA Noviekayati dan Dyan Evita Santi \\ Universitas 17 Agustus 1945 Surabaya, Indonesia \\ Email: imamshofii7509@gmail.com, ekayatinovi@gmail.com dan \\ arma_luna@yahoo.com3
}

\begin{abstract}
This study aims to determine the effectiveness of music therapy to increase subjective well-being of the elderly in the area of Puskesmas Modung Bangkalan. This research is a quantitative, pre-experimental study. The type of experimental design used is the re-treatment design (one group pretest posttest design) which is an experimental design that only uses one group of subjects (single cases) and takes measurements before and after giving treatment to the subject. This study was conducted on elderly people who experienced low subjective well-being during the Covid-19 pandemic with a total sample of 50 people who were taken using purposive sampling technique method. The results showed that music therapy was effective in increasing Subjective Well-Being in the elderly. In addition, this study also found differences in Subjective Well-Being between the elderly Woman with Boy.
\end{abstract}

Keywords: subjective well-being; music therapy; gender; elderly

\begin{abstract}
Abstrak
Penelitian ini bertujuan untuk mengetahui efektivitas terapi musik untuk meningkatkan subjective well-being pada lanjut usia di wilayah Puskesmas Modung Bangkalan. Penelitian ini merupakan penelitian kuantitatif, praeksperimen. Jenis desain eksperimen yang digunakan adalah desain perlakuan ulang (one group pretest posttest design) merupakan desain eksperimen yang hanya menggunakan satu kelompok subjek (kasus tunggal) serta melakukan pengukuran sebelum dan sesudah pemberian perlakuan pada subjek. Penelitian ini dilakukan terhadap lanjut usia yang mengalami subjective well-being rendah dimasa pandemi covid-19 dengan jumlah sampel 50 orang yang diambil menggunakan metode teknik purposive sampling. Hasil penelitian menunjukkan bahwa terapi music efektif meningkatkan subjective well-being pada lanjut usia. Selain itu penelitian ini juga menemukan ada perbedaan subjective well-being antara lansia Perempuan dengan Laki-laki.
\end{abstract}

Kata kunci: subjective well-being; terapi musik; jenis kelamin; lanjut usia 
Efektivitas Terapi Musik untuk Meningkatkan Subjective Well Being pada Lanjut Usia ditinjau dari Jenis Kelamin di Wilayah Puskesmas Modung Kabupaten Bangkalan

Coresponden Author

Email: imamshofii7509@gmail.com Artikel dengan akses terbuka dibawah lisensi

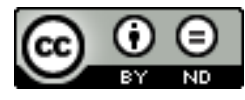

\section{Pendahuluan}

Pada tahun 2020 jumlah lanjut usia Di Indonesia diperkirakan akan mencapai 28,8 juta orang atau 11,34 persen. Sebaran penduduk lanjut usia tahun 2017 di Indonesia. Jawa Timur berada di urutan ketiga tertinggi yaitu 2,9 juta (12,25\%) (Badan Pusat Statistik, 2015). Dari jumlah rasio penduduk lanjut usia di Jawa Timur yaitu 12,25\%, maka diperoleh jumlah penduduk lanjut usia di wilayah Puskesmas Modung sebesar 12.000 jiwa.

Data tersebut tentu belum memiliki makna yang strategis jika tidak dihubungkan dengan data-data lain yang berkaitan dengan kelompok lanjut usia tersebut, dalam hal ini penulis ingin mengetahui dinamika subjective well-being penduduk lanjut usia di wilayah kerja Puskesmas Modung. Peneliti menggunakan istilah subjective well-being (SWB) untuk menggambarkan kebahagiaan seseorang, karena mengacu pada pendapat Luthans bahwa istilah SWB lebih tepat dan dapat didefinisikan secara operasional. Secara sederhana definisi dari subjective well-being adalah persepsi seseorang terhadap pengalaman hidupnya yang terdiri dari evaluasi kognitif dan afeksi terhadap hidup dan mempresentasikan dalam kesejahteraan psikologis.

Subjective well-being terletak pada pengalaman setiap individu yang merupakan pengukuran positif dan secara khas mencakup pada penialaian dari seluruh aspek kehidupan. Diener, Suh, \& Oishi dalam (Eid and Larsen 2008), menjelaskan bahwa individu dikatakan memiliki subjective well-being tinggi jika mengalami kepuasan hidup, sering merasakan kegembiraan, dan jarang merasakan emosi yang tidak menyenangkan seperti kesedihan atau kemarahan. Sebaliknya, individu dikatakan memiliki subjective well-being rendah jika tidak puas dengan kehidupannya, mengalami sedikit kegembiraan dan afeksi, serta lebih sering merasakan emosi negatif seperti kemarahan atau kecemasan.

(Rahayu 2016) menyatakan bahwa umur dan jenis kelamin memiliki hubungan dengan subjective well being namun pengaruhnya kecil bergantung pada segi sudut komponen dari subjective well being yang akan diukur.

Penelitian yang juga dilakukan oleh Wilson mengungkapkan jika usia muda pada seseorang dianggap mencerminkan keadaan yang lebih bahagia. Namun setelah diteliti lebih dalam ternyata usia tidak berhubungan dengan kebahagiaan yaitu kepuasan hidup, afek positif dan afek negatif. Kepuasan hidup sedikit meningkat sejalan dengan bertambahnya usia, afek positif sedikit melemah dan afek negatif tidak berubah. (Seligman 2002) menjelaskan hal yang berubah ketika seseorang menua adalah intensitas emosi dimana perasaan mencapai puncak dan terpuruk dalam keputusasaan berkurang seiring dengan bertambahnya umur dan pengalaman. 
Hal tersebut membuat para lanjut usia banyak mengalami kepuasan hidup yang tidak menyenangkan baik didalam keluarga maupun dalam diri sendiri. Maka dengan kondisi lanjut usia yang memperhatinkan peneliti ingin membantu untuk meringankan beban atau masalah dengan memberi psikoedukasi dan terapi yang sesuai untuk lanjut usia yang sedang mengalami pengalaman hidupnya yang kurang menyenangkan.

Biasanya para lanjut usia bisa bekerja dan beraktivitas karena ada sesuatu yang hendak dicapainya, dan orang itu berharap bahwa aktivitas kerja yang dilakukannya akan membawanya kepada suatu keadaan yang lebih memuaskan daripada keadaan sebelumnya. Melalui bekerja setiap orang akan mendapatkan input berupa upah/gaji/bonus yang tentu bisa mensejahterakan kehidupan sehari-hari dengan adanya pandemi Covid 19 maka aktivitas terganggu bahkan tidak bisa berbuat sesuatu karena ada peraturan yang harus diikuti dan dijalankan sesuai aturan yang ada setempat.

Berdasarkan data yang diperoleh, penulis menganalisa bahwa jumlah lanjut usia yang mengalami kepuasan hidup yang tidak menyenangkan diantaranya perempuan dan laki-laki. Untuk itu penulis juga ingin melihat pengaruh jenis kelamin terhadap dinamika derajat subjective well-being kelompok lanjut usia, karena ada sejumlah penelitian yang menggambarkan subjective well-being adalah persepsi seseorang terhadap pengalaman hidupnya, yang terdiri dari evaluasi kognitif dan afeksi terhadap hidup dan mempresentasikan dalam kesejahteraan psikologis.

Tujuan terapi musik di Wilayah Puskesmas Modung meningkatkan subjective well-being pada lanjut usia Menurut (Ryff. C. \& Keyes. C 2005) aspek subjective wellbeing terdiri dari: Penerimaan diri, yaitu pemahaman yang jelas akan peristiwa yang terjadi sehingga individu dapat memberikan tanggapan secara efektif, hubungan positif dengan orang lain, seseorang dengan subjective well-being yang tinggi mempunyai ciriciri berhubungan sosial yang baik, otonomi/kemandirian, mampu untuk mengambil keputusan tanpa tekanan dan campur tangan orang lain. Selain itu orang tersebut memiliki ketahanan dalam menghadapi tekanan sosial, dapat mengatur tingkah laku dari dalam diri, serta dapat mengevaluasi diri dengan standard personal, penguasaan lingkungan, mampu mengatur dan mengendalikan situasi kehidupan sehari-hari, memanfaatkan kesempatan yang ada di lingkungannya, serta mampu memilih dan menciptakan lingkungan yang sesuai dengan kebutuhan dan nilai-nilai pribadi, tujuan hidup dapat memahami makna hidup dan mampu mengatasi masalah, hal itu memiliki arti pada masa sekarang dan masa lalu dalam kehidupan. Sedangkan orang yang komitmen dalam hidupnya kurang maka dia tidak mampu memaknai hidup, pertumbuhan pribadi yang berkemban pribadi yang mempunyai locus of control sebagai alat evaluasi, dimana seseorang tidak melihat orang lain untuk mendapatkan persetujuan, tetapi mengevaluasi diri dengan menggunakan standard pribadinya

Sehubungan dengan jenis kelamin ada sedikit pengaruh, karena perbedaan keduanya. Jenis kelamin, memiliki hubungan dengan keadaan hati. Perempuan lebih banyak mengalami emosi positif dengan intensitas yang lebih tinggi dibandingkan dengan Laki-laki. Tingkat emosi rata-rata Laki-laki dengan Perempuan tidak berbeda 
Efektivitas Terapi Musik untuk Meningkatkan Subjective Well Being pada Lanjut Usia ditinjau dari Jenis Kelamin di Wilayah Puskesmas Modung Kabupaten Bangkalan

namun Perempuan sering merasakan emosi negatif seperti kemarahan atau kecemasan. daripada Laki-laki (Darmojo 2011).

Sedangkan untuk jenis kelamin, (Rahayu 2016) menyatakan bahwa secara umum tidak terdapat perbedaan subjective well being yang signifikan antara laki-laki dan Perempuan Namun perempuan memiliki intensitas perasaan negatif dan positif yang lebih banyak dibanding laki-laki. Secara psikologis membutuhkan intervensi psikologi tertentu yang bisa memperbaiki atau meningkatkan subjective well-being. Intrervensi psikologis yang diyakini mudah dan murah, efektif dan efisien adalah intervensi psikologis dengan menggunakan terapi musik, karena terapi musik dalam berbagai penelitian bisa menunjukkan hasil yang positif terhadap kondisi psikologis seseorang.

Terapi musik sendiri merupakan intervensi yang sedang berkembang belakangan ini sebagai sebuah intervensi sistematis dengan terapis yang membantu klien untuk meningkatkan kesehatan menggunakan pengalaman musik dan hubungan yang berkembang diantaranya sebagai kekuatan dinamis perubahan (Bruscia 2014) musik adalah terapi yang menggunakan musik atau terapi yang bersifat nonverbal (Wu et al. 2006). Menurut (Suryana 2012) terapi musik adalah proses yang menggunakan musik untuk terapi aspek-fisik, emosional, mental, sosial, estetika dan spiritual untuk meningkatkan atau mempertahankan kesehatan mereka.

Terapi musik juga mempunyai tujuan untuk membantu mengekspresikan perasaan, membantu rehabilitasi fisik, memberi pengaruh positif terhadap kondisi suasana hati dan emosi serta mengurangi tingkat kecemasan pada pasien (Wu et al. 2006).

Terapi musik yang efektif menggunakan musik dengan komposisi yang tepat antara tempo, ritme dan harmoni yang disesuaikan dengan tujuan dilakukannya terapi musik. Jadi memang terapi musik yang efektif tidak bisa menggunakan sembarang musik (Wu et al. 2006).

Musik yang sesuai untuk meningkatkan subjective well-being lanjut usia yaitu suara alam karena suara alam sangat dekat dengan setiap orang dalam kehidupan sehariharinya dan manusia memiliki daya tarik bawaan dengan alam sehingga interaksinya dengan alam memiliki efek terapetik terhadap manusia itu sendiri ((Wijayanti 2016).

Mendengarkan suara alam juga merupakan salah satu teknik relaksasi. Suara alam seperti suara air hujan, aliran sungai, suara burung di hutan, suara ombak pantai dan suara hembusan angin merupakan suara-suara yang dekat dengan setiap orang dalam kehidupan sehari-harinya tetapi penggunaan suara alam tersebut dalam tatanan klinik masih jarang dilakukan. E.O.Wilson dalam bukunya Biophilia mengemukakan bahwa manusia memiliki daya tarik bawaan dengan alam sehingga interaksinya dengan alam memiliki efek terapetik terhadap manusia itu sendiri (Wijayanti 2016).

Rata-rata jenis musik relaksasi yang digunakan dalam beberapa penelitian tersebut adalah jenis musik yang lembut, musik klasik dan musik tradisional yang semuanya tidak menggunakan lirik dengan beat 60-80 beat per minutes (bpm). Suara alam yang digunakan dalam penelitian-penelitian tersebut rata-rata adalah suara burung di hutan, suara gemericik air hujan, suara katak di persawahan, suara gelombang dan hembusan angin pantai serta suara air terjun. Hasil review juga menjelaskan bahwa terapi ini 
didengarkan selama lebih kurang 20-30 menit dengan kondisi subyek dibuat senyaman mungkin, rileks, lingkungan dimodifikasi tenang dan subyek bisa diistruksikan untuk menutup mata sementara supaya lebih rileks. Media yang digunakan rata-rata adalah CD player atau MP4 player dengan headphone atau earphone.

Suara musik tersebut selain menstimulus munculnya gelombang alfa $(7-13 \mathrm{~Hz})$, juga menstimulus munculnya gelombang delta $(0,5-4 \mathrm{~Hz})$, dan theta $(4-8 \mathrm{~Hz})$. Gelombang delta mengindikasikan bahwa kondisi klien berada dalam keadaan sangat nyaman karena dalam keadaan ini gelombang otak semakin melambat sehingga terjadi kondisi tidur yang sangat dalam pada klien. Sedangkan gelombang alfa merupakan pintu masuk ke dalam pikiran bawah sadar dimana informasi akan masuk kedalam pikiran bawah sadar Pada kondisi ini otak memproduksi hormon serotonin danendorfin yang menyebabkan seseorang merasa nyaman, tenang dan bahagia (Soyer et al. 2017).

Hal ini disebabkan musik memiliki beberapa kelebihan, yaitu karena music bersifat nyaman, menenangkan, membuat rileks, berstruktur, dan universal. Perlu diingat bahwa banyak dari proses dalam hidup kita selalu ber-irama. Sebagai contoh, nafas kita, detak jantung, dan pulsasi semuanya berulang dan berirama.

\section{Metode Penelitian}

Dalam penelitian ini teknik sampling atau pengambilan sampel dengan menggunakan metode teknik purposive sampling, artinya pengambilan sekelompok subjek dengan cara menentukan terlebih dahulu jumlah sampel yang dikehendaki berdasarkan ciri-ciri atau sifat-sifat tertentu yang dipandang mempunyai sangkut paut yang erat dengan sifat populasi yang sudah diketahui sebelumnya. Kategori/Jenis-jenis subjek dalam penelitian ini sudah ditentukan oleh peneliti yang akan terlibat harus memiliki kriteria :

a) Lanjut usia yang berada di Wilayah Puskesmas Modung

b) Berusia antara 60-90 tahun

c) Mengalami subjective well-being rendah

d) Bersedia menjadi dan mengikuti keseluruhan dari proses penelitian berdasarkan pengisian informed concern.

Tabel 1

Desain Tahapan Atau Prosedur Penelitian

\begin{tabular}{llll}
\hline Jenis & Pre-test & pelakuan & Pos-test \\
\hline kelamin & & & \\
\hline Laki-laki & O1 & $\begin{array}{l}\text { X Terapi } \\
\text { Musik }\end{array}$ & O2 \\
\hline Perempuan & O1 & & O2 \\
\hline
\end{tabular}

nonR O1 - (X) O2

Keterangan:

O1 = Pre-test

$\mathrm{X}=$ Perlakuan Terapi MusikO2 = Post-test 
Menurut penelitian (Kemper and Danhauer 2005), bahwa musik secara luas digunakan untuk meningkatkan kesejahteraan, mengurangi stress, dan mengalihkan perhatian pasien dari gejala yang tidak menyenangkan, sehingga dengan demikian jelas bahwa terapi musik berpengaruh terhadap kondisi emosional seseorang.

Musik merupakan salah satu elemen yang tidak bisa dilepaskan dalam keseharian. Rangkaian nada alunan musik mampu meningkatkan mood dan memengaruhi kondisi psikologis seseorang. musik juga bisa sebagai sarana relaksasi maupun terapi, membantu memperbaiki kondisi depresi, pasien diharapkan mau berobat. Kemauan melawan penyakit akan memperbaiki kualitas hidup pasien, yang menentukan kesembuhannya.

Dalam Pelatihan terapi musik ini menggunakan dua metode yang pertama adalah metode ceramah dan tanya jawab serta yang ke dua role play. Melalui metode ceramah dan tanya jawab ini diharapkan subyek dalam peenlitian diajak untuk mengenal musik manfaat dari terapi. Untuk sesi role play, dalam sesi ini peserta akan diajak untuk bersama-sama ikut serta dalam mempraktekkan teknik terapi music.

\section{Hasil dan Pembahasan}

1. Hipotesis pertama berbunyi "Terapi musik efektif meningkatkan subjective wellbeing pada lanjut usia" Hasil analisis uji paired sampel t-tes diperoleh data nilai $t$ hitung sebesar -9.324 dengan taraf signifikansi. 0,000. Karena taraf signifikansi lebih kecil dari $0,05(\mathrm{p} \leq 0,05)$, maka hipotesis pertama ada perbedaan subjective well-being pada lanjut usia sebelum dan sesudah diberikan terapi musik suara alam. Oleh karena itu dapat dinyatakan bahwa Terapi musik suara alam efektif untuk meningkatkan tingkat subjective well-being lanjut usia di Wilayah Puskesmas Modung Dengan demikian hipotesis yang berbunyi "Terapi musik efektif meningkatkan subjective well-being pada lanjut usia". Diterima

2. Hipotesis kedua berbunyi perbedaan subjective well-being antara lanjut usia laki-laki dan lanjut usia perempuan Berdasarkan hasil analisis uji independent paired sampel t-test diperoleh nilai sig. (2-tailed) atau taraf signifikansi 0,054 ( $\mathrm{p}>0,05)$ maka dapat disimpulkan bahwa tidak ada perbedaan subjective well-being antara lanjut usia lakilaki dan lanjut usia perempuan. Dengan demikian hipotesis yang berbunyi "Tidak ada perbedaan subjective well-being pada lanjut usia laki-laki dan lanjut usia perempuan". Ditolak

Terdapat beberapa hasil dalam penelitian ini, dimana hasil-hasil tersebut menurut lanjut usia di Wilayah Puskesmas Modung. Musik sebagai alat terapi yakni mempengaruhi semua organ sistem tubuh. Menurut teori Candace Pert bahwa neuropeptida dan reseptor-reseptor biokimia yang dikeluarkan oleh hipotalamus berhubungan erat dengan kejadian emosi (Djanuar and Huda 2020). Sifat riang atau rileks mampu mengurangi kadar kortisol, epinefrin-norepinefrin, dopa dan hormon pertumbuhan di dalam serum .

Berikut gambaran mekanisme sensasi musik terhadap fisiologi tubuh manusia. Otak bagian kiri adalah proses analisa, kognitif, dan aktivitas, sedang otak kanan 
sebagai proses artistik, aktivitas imaginasi. Unsur-unsur musik yakni irama, nada dan intensitasnya masuk ke kanalis auditorius teliga luar yang disalurkan ke tulang-tulang pendengaran. Musik tersebut akan dihantarkan sampai ke thalamus. Musik mampu mengaktifkan memori yang tersimpan di limbic dan mempengaruhi sistem syaraf otonom melalui neurotransmitter yang akan mempengaruhi hipotalamus lalu ke hipofisis.

Musik yang telah masuk ke kelenjar hipofisis mampu memberikan tanggapan terhadap emosional melalui feedback negatif ke kelenjar adrenal untuk menekan pengeluaran hormon epinefrin, norepinefrin dan dopa yang disebut dengan hormonhormon stress. Masalah mental seperti ketengangan, stress berkurang, tubuh menjadi lebih rileks (Nichols and Humenick 2000).

Tujuan terapi musik di Wilayah Puskesmas Modung untuk meningkatkan subjective well-being pada lanjut usia terdiri dari: Penerimaan diri, pemahaman yang jelas akan peristiwa yang terjadi sehingga individu dapat memberikan tanggapan secara efektif. Hubungan positif dengan orang lain, seseorang dengan subjective well-being yang tinggi mempunyai ciri-ciri berhubungan sosial yang baik.

Otonomi/kemandirian, mampu untuk mengambil keputusan tanpa tekanan dan campur tangan orang lain. Selain itu, orang tersebut memiliki ketahanan dalam menghadapi tekanan sosial, dapat mengatur tingkah laku dari dalam diri, serta dapat mengevaluasi diri dengan standard personal. Penguasaan lingkungan, Mampu mengatur dan mengendalikan situasi kehidupan sehari-hari, memanfaatkan kesempatan yang ada di lingkungannya, serta mampu memilih dan menciptakan lingkungan yang sesuai dengan kebutuhan dan nilai-nilai pribadi.

Tujuan hidup dapat memahami makna hidup dan mampu mengatasi masalah. Hal itu memiliki arti pada masa sekarang dan masa lalu dalam kehidupan. Sedangkan orang yang komitmen dalam hidupnya kurang maka dia tidak mampu memaknai hidup. Pertumbuhan pribadi yang berkembang pribadi yang mempunyai locus of control sebagai alat evaluasi, dimana seseorang tidak melihat orang lain untuk mendapatkan persetujuan, tetapi mengevaluasi diri dengan menggunakan standard pribadinya. Sedangkan untuk jenis kelamin, (Rahayu 2016) menyatakan bahwa secara umum tidak terdapat perbedaan subjective well-being yang signifikan antara laki-laki dan perempuan namun perempuan memiliki intensitas perasaan negatif dan positif yang lebih banyak dibanding laki-laki.

\section{Kesimpulan}

Berdasarkan hasil penelitian dan pembahasan sebelumnya, maka kesimpulan yang dapat peneliti ajukan adalah:

1. Menerapkan terapi musik sebagaimana yang telah dilatihkan dalam penelitian ini dalam kehidupan sehari-hari supaya dapat membantu meningkatkan subjective wellbeing.

2. Mempertimbangkan penggunaan terapi music secara periodic guna meningkatkan subjective well-being para lanjut usia di masa pandemi Covid-19. 
Efektivitas Terapi Musik untuk Meningkatkan Subjective Well Being pada Lanjut Usia ditinjau dari Jenis Kelamin di Wilayah Puskesmas Modung Kabupaten Bangkalan

\section{BIBLIOGRAFI}

Bruscia, K. 2014. "Self-Experiences in the Pedagogy of Music Therapy." SelfExperiences in Music Therapy Education Training, and Supervision 15-33.

Darmojo, B. 2011. "Buku Ajar Geriatic (Ilmu Kesehatan Lanjut Usia) Edisi Ke-4." Jakarta: FKUI.

Djanuar, Nera, and Irpan Pahmil Huda. 2020. "Pengaruh Terapi Musik Shalawat Terhadap Kecemasan Pasien Pre Operasi Di Rsud 45 Kuningan Tahun 2019.” Journal of Nursing Practice and Education 1(1).

Eid, Michael, and Randy J. Larsen. 2008. The Science of Subjective Well-Being. Guilford Press.

Kemper, Kathi J., and Suzanne C. Danhauer. 2005. "Music as Therapy." South Med J 98(3):282-88.

Nichols, Francine H., and Sharron Smith Humenick. 2000. Childbirth Education: Practice, Research and Theory. WB Saunders company.

Rahayu, Ika Kurnia. 2016. "Kesejahteraan Subjektif (Subjective Well-Being) Pada Istri Narapidana Sekaligus Penderita Kanker Ovarium: Studi Kasus Di Desa Ngajum Kabupaten Malang."

Ryff. C. \& Keyes. C. 2005. "The Ryff Scales of Psychological Well-Being. Journal of Personality and Social Psychology. Vol 69. No. 4."

Seligman, M. E. P. 2002. “Autenthic Happiness. Bandung: Mizan Media Utama.”

Soyer, Wolfgang, Randall Mackie, Stephen Hallinan, Alice Pavesi, Gregg Nordquist, A. Suminar, R. Intani, and C. Nelson. 2017. "Multi-Physics Imaging of the Darajat Field." GRC Transactions 41.

Suryana, Dayat. 2012. Terapi Musik: Music Therapy 2012. CreateSpace Independent Publishing Platform.

Wijayanti, Kurnia. 2016. "Nature Sounds Music to Decreased Anxiety on Critically Ill Patients." Nurscope: Jurnal Penelitian Dan Pemikiran Ilmiah Keperawatan 2(2):20-29.

Wu, Liza C., Risal S. Djohan, Tom S. Liu, Albert H. Chao, Robert F. Lohman, and David H. Song. 2006. "Proximal Vascular Pedicle Preservation for Sartorius Muscle Flap Transposition." Plastic and Reconstructive Surgery 117(1):253-58. 